\title{
ALFRED MARSHALL ON BIG BUSINESS
}

Jaques Kerstenetzky ${ }^{1}$

This paper is about the way Alfred Marshall, the champion of the family-owned and -managed firm, approached the phenomenon which Alfred Chandler considered as the emergence of a new kind of capitalism and enterprise, characterized by the presence of corporations. ${ }^{2}$

The examination of the theme involves history and theory. And, following Marshall's judgment that history is not a purely inductive practice, nor is theory a purely deductive one, it is an opportunity for reflecting on the historical and institutional content of Marshall's perusal of firm's nature, size, organization and coordination. The task includes the identification of some connections among the work of the two Alfreds.

The theme inevitably refers to the classical issue of the dilemma of increasing returns and competition. The dilemma will be presented as the theoretical context and will work as a unifying thread through the paper.

The paper is organized in two parts. The first part is an introduction to the Marshallian approach on business organization issues. It shall place Marshall's work into historical context, and characterize Marshall's work in a way which is different from how he is read and was incorporated into economic theory by mainstream economics. The second part specifically approaches Industry and Trade, the book in which Marshall discussed business organization in depth. $^{3}$

\section{Introduction to Marshall's work on business organization}

\subsection{The historical and theoretical context of Marshall's work on business organization}

The historical economic context of Marshall's writings is the second industrial revolution, hatched in the last quarter of the nineteenth century. The revolution consisted of new technologies and economic activities that involved massive scale economies, giving birth to large firms and monopolistic tendencies. The English nineteenth century typical leading business unit and its corresponding business organization, centered on small industrial firms owned and managed by families and partnerships, was giving place to the capitalism of large German and American corporations, share-owned and professionally managed, which would become the leading agent and characterize the capitalist environment of production.

The transformation in the business environment emphasized a question which was at least latent in economic theory since Adam Smith: ${ }^{4}$ the reconciliation of competition and increasing returns. This problem is habitually seen as impossibility, with increasing returns and competition standing as the two sides of a dilemma.

\footnotetext{
${ }^{1}$ Professor Adjunto do Instituto de Economia da UFRJ.

${ }^{2}$ As I learned from Loasby(1989), and among the many keys he provides for understanding Marshall, reading this author is not an easy task, because we tend to see in his writings largely a reflection of our viewpoints. I must acknowledge here that the interpretation presented in this text follows the reading lenses provided by Brian Loasby and other Marshallians.

${ }^{3}$ Yet, along the paper, Principles of Economics shall have an important presence. Principles' references in the text refer to the eighth edition, and will indicate, in this order, book, chapter and section of chapter. The same procedure will be used for Industry and Trade references.

${ }^{4}$ Stigler (1951).
} 


\subsection{Methodological aspects of the dilemma and Marshall's approach}

If the problem of increasing returns is statically tackled, that is, considering only the forces that are present at a point in time and with every firm having the same access to opportunities and capabilities, as was the habit of our profession during a long time, there is no solution, and there is really a dilemma: either we consider increasing returns and the first firm to adopt the more economic scale in relation to the size of the market takes the whole of it and becomes monopolist, or we ban increasing returns from theory and we are able to maintain competition. ${ }^{5}$

A full-blown static representation of the problem can be found in the following passage from Marshall's Principles, in which the author refers to other's concerns:

Some, among whom Cournot himself is to be counted, have before them what is in effect the supply schedule of an individual firm; representing that an increase in its output gives it command over so great internal economies as much to diminish its expenses of production; and they follow their mathematics boldly, but apparently without noticing that their premises lead inevitably to the conclusion that, whatever firm first gets a good start will obtain a monopoly of the whole business of its trade in its district. While others avoiding this horn of the dilemma, maintain that there is no equilibrium at all for commodities which obey the law of increasing return; and some again have called in question the validity of any supply schedule which represents prices diminishing as the amount produced increases.

(Principles, V,12,fn 6).

This passage calls out Marshall's methodological proposition that "The function [...] of analysis and deduction in economics is not to forge a few long chains of reasoning, but to forge rightly many short chains and single connecting links". ${ }^{6}$ The method he advocated was a combination of induction and deduction, so that immediate logical implications would be balanced with experience. In this way, history and institutions are brought into the analysis. According to his methodological procedures, Marshall would not push the logical implications of increasing returns and size to its last consequences. This appears to explain what Marshall means when he refers to, in the passage above, "they follow their mathematics boldly". 7

If, however, the problem is dynamically addressed, competition is a process and it takes time for the firm to grow; market and capabilities are arduously acquired and accumulated, and growth modifies the firm; and the economic environment is always changing, not only because underlying circumstances change but also, and more importantly, as a consequence of the moves of the competing agents themselves. Actually, this was the picture of competition Marshall implicitly used in his work. ${ }^{8}$

\footnotetext{
${ }^{5}$ Still, if we relax the premise of same access to opportunities in the form of assuming consumer preferences for the products of specific producers, Sraffa's (1926) solution can follow. However, we will not consider this static solution here because it is a very restrict introduction of marketing issues. We want to emphasize the many sided nature of entrepreneurship, production and marketing being part of the issue, as Marshall considered.

${ }^{6}$ Principles, appendix C,3.

${ }^{7}$ See Coase (1975) for details on Marshall's methodological convictions.

${ }^{8}$ Marshall's views on competition are scattered in his works. The statement in this paper is based on his analysis of the qualities of the entrepreneur and his devising of new solutions to the various aspects of business, the explanations for the decay of old firms (Principles, IV, XII), and his perception of progress and constant change that turns the word of business constantly more complex.
} 
Marshall's work is better understood if, instead of considering the parts which were selected by the mainstream for posterior development, we reflect on his overall project of building a dynamic approach to the capitalist functioning, in the sense of one that would contribute to the "understanding of the process of economic development, a process which was essentially evolutionary in nature." Proceeding this way, we will consider his value theory, i.e., the theoretical piece incorporated into the partial equilibrium branch of mainstream economics, in the same way as Marshall himself did - as a static analysis which is only a first approximation to economic problems. ${ }^{10}$

If we take the undelivered second volume planned for the Principles as a significant stage of the overall project, we are left with the perception that Marshall died without accomplishing it. Selfdemand, and others' as well, such as participation in governmental commissions and public service, deviations as the study of history and illness are the reasons we find in biographic works for the difficulties that hindered Marshall from writing and publishing the second volume. ${ }^{11}$ In the last years of his life, he organized the writings accumulated after the publication of the Principles in two books, the first of them being Industry and Trade. It is not a dynamic theory of the capitalist system, which Marshall could not formulate, but besides a study of business organization, it is a historical-institutional analysis of it. Nowadays, with new perspectives and important institutional and methodological issues coming up, it is worth considering Marshall's achievements in business organization.

\subsection{The dilemma in the Principles and in the Industry and Trade}

If we carefully analyze the Principles of Economics, considered as Marshall's magnum opus, we find in it much more than the static value theory. The Principles have much rich institutional and historical material, which was left aside by the posterior development of the study of firms and markets as a partial equilibrium problem.

In the Industry and Trade, having worked out the value theory in the Principles, Marshall only had to make short references to it when needed. The book's content is historical and institutional.

Comparing the two books we observe that, if there are differences in the mix of degrees of abstraction, there is no change in his methodology, values or vision of capitalism. Both books here dealt with can be considered as specialized parts of the same effort. We can notice that the picture of the business organization framed in his most famous book does not collide with that of the Industry and Trade.

However, specifically addressing the dilemma of increasing returns and competition, we can observe that these two books had different approaches for it.

The first approach, from the Principles, consists in avoiding big business with the life cycle of firms. Increasing returns would not lead to monopoly because the capitalist environment is marked by permanent change. Outside the static framework, a bigger size does not mean a choice located towards the right portion of the cost curve, but the outcome of the growth process. As this process takes time, older and bigger firms managed by heirs using old solutions to entrepreneurial problems would tend to decay, being replaced by new firms created by vigorous entrepreneurs who undertake creative moves. Marshall observed that heirs do not have the same qualities and motivations of the founders, and are not selected by the market, as were the

\footnotetext{
${ }^{9}$ Hart (1996, p.286) argues in this sense, using Marshallian citations.

${ }^{10}$ Principles, V,V,3; V,XII,3 and V,XIV,4.

${ }^{11}$ Groenewegen (1995) and Whitaker (1990) are excellent sources on the history of Marshall's writings.
} 
entrepreneurial founders to whom they succeed. ${ }^{12}$

This last proposition was framed by Marshall with family firms in mind. However, considering the growing importance of joint-stock business organization, Marshall gave it increasing attention in the last editions of the Principles. ${ }^{13} \mathrm{He}$ did not consider that the tendency of firms to decay would be nullified by the new institutional form, because it had its own flaws. Anyway, he though the new kind of firm appeared to be more resilient because of advantages brought by size. Corporations received a more detailed treatment in the Industry and Trade.

A perusal of the dilemma in the Industry and Trade points out that big business is explicitly recognized, and historically and institutionally analyzed. Competition is presented (scattered along the book) as a process in which giant enterprises take active part, and no trace is found of what would later become the perfect competition model. In this book, Marshall observed that the size of the typical plant was increasing with time, and that the growth of the firm was also assuming the form of combinations, as in the case of the American trusts and German cartels. As an analyst of business organization, Marshall saw these tendencies as historical, and tried to understand which the conditions were that would bring about a healthy economic environment, even with combinations, growth in size, and in market power. In sum, there is no dilemma, because it is solved by historical and institutional analysis, in which competition is a dynamic process.

\subsection{Elements of the Marshallian approach to business}

In this section we take up Marshall's view on the firm and its nature as the business agent. We shall see that the Marshallian firm is not an element of a static world of resource allocation, but an element of an evolving business environment.

Marshall does not analyze production as simple combination of capital, labor, and natural resources. Firms, markets, and economies must count on organization and knowledge in addition to those resources. ${ }^{14}$ Therefore, knowledge and organization must be privately and publicly developed and held. ${ }^{15}$ At private levels, there are the capabilities, experience, and solutions internally developed by individual firms; at public levels, there are the secrets of production and trade, practices, relationships, institutions shared inside sectors and specialized industrial districts, and those that result from the interaction between different sectors of economic activity; there is still the governmental activity providing a legal framework for the entire economy.

An important question to raise refers to the nature of the firm. The Marshallian answer ${ }^{16}$ is developed in Principles, book IV, chapter XII, and begins with the assertion that

$[\ldots]$ in the greater part of the business of the modern world the task of so directing production that a given effort may be most effective in supplying human wants has to be broken up and given into the hands of a specialized body of employers, or to use a more general term, of business men. They "adventure" or "undertake"

\footnotetext{
${ }^{12}$ Principles, IV, XII,6 and IV,XII,1.

${ }^{13}$ Principles, IV, XII.

${ }^{14}$ Principles, IV, 1, 1.

${ }^{15}$ Judging knowledge and organization fundamental elements of material wealth, Marshall, in the paragraph of the last footnote reference, considered them as part of capital. Not discussing this here, it is important to note that these were for him elements to be analyzed in economic theory, instead of being skipped with the easy solution of considering them free goods. The importance of knowledge and organization is analyzed in many of Loasby's works.

${ }^{16}$ We are considering firm and entrepreneur's capabilities as interchangeable in the environment of family firms.
} 
its risks; they bring together the capital and the labour required for the work; they arrange or "engineer" its general plan, and superintend its minor details. Looking at business men [...] we may regard them as a highly skilled industrial grade [...] (Principles, IV,XII,2)

The passage proposes that entrepreneurs are endowed with specific abilities that enable them to bring together capital and labor in the form of carefully planned and supervised activities; it also stresses the "risky" nature of the enterprise. It is important to notice that, from the modern point of view, Marshal uses the word risk in a loose manner. From a broad perspective of his writings, we can state that he uses "risk" in the sense that Knight would use "uncertainty".

Marshall details entrepreneur's capabilities, grouping those under two classes. One of them is the

[...] role of employer [in which] he must be a natural leader of men. He must have a power of first choosing his assistants rightly and then trusting them fully; of interesting them in the business and of getting them to trust him, so as to bring out whatever enterprise and power of origination there is in them; while he himself exercises a general control over everything, and preserves order and unity in the main plan of the business.

(Principles,IV,XII,5)

That is, the leader of men function in part corresponds to the modern issue of envisaging incentives and monitoring, though with a more human content because this ability leaves room for idiosyncratic character in the Marshallian presentation; and also includes internal coordination of the business unity, both in terms of planning and execution.

Besides the organization and supervision of the internal activities, the entrepreneur must

[...]have a thorough knowledge of things in his own trade. He must have the power of forecasting the broad movements of production and consumption, of seeing where there is an opportunity for supplying a new commodity that will meet a real want or improving the plan of producing an old commodity. He must be able to judge cautiously and undertake risks boldly; and he must of course understand the materials and machinery used in his trade.

(Principles, book IV, Chapter XII, Par. 5)

In this second passage we can observe the operation of knowledge, not only related to technical issues, but in the form of capability related to the decision process under uncertainty because of the necessity of dealing with the future through conjectures.

The capabilities of the firm described are set in motion in section 6 of Chapter XII, Book IV of The Principles of Economics. There we see the Marshallian firm as a capitalist agent, in the sense that it expands itself, resembling the classical economists' firm that accumulates capital. Yet the growth of the Marshallian firm is not mere capital accumulation. It is also accumulation of skills and knowledge, development of an internal organization (including hierarchy and labor relations) and creation of a clientele. This makes Marshall a forerunner of more recent approaches to firms as Edith Penrose's Theory of the Growth of the Firm, and a precursor of the modern organizational capabilities approach. ${ }^{17}$

\footnotetext{
${ }^{17}$ For a recent appraisal of the organizational capabilities approach (including the possibility of its integration with the neo-institutional), see Langlois and Foss (1999). Chandler (1992) has also worked on the theme.
} 
Marshallian firms develop their skills and knowledge in a competitive and innovative environment, in which their survival and their growth depend on their ability in introducing new solutions for business issues, and in coping with problems brought about by growth. Solutions emerge in many areas of entrepreneurial activity, such as technical capacity, labor organization, and relationship with suppliers and customers. This last point is deducted from Marshall's proposition that while

His sons find a firmly established trade connection, and what is perhaps even more important, a well-chosen staff of subordinates with a generous interest in the business. [...]. But when a full generation has passed, when the old traditions are no longer a safe guide and when the bonds that held together the old staff have been dissolved, then the business almost invariably falls to pieces [...]

(Principles,IV,XII,6, emphasis added)

And it corresponds to an implicit assertion that Marshall sees the entrepreneurial environment as heterogeneous and in constant change, though without the radical aspect of Schumpeterian creative destruction. We can extend the reasoning: In a Marshallian competitive environment, some firms appear and survive by opening their way with forceful solutions to particular aspects of business, while others are growing and coping with the problems of reaping increasing returns and selling increasing quantities, and still others are ossified and decaying, using old solutions that once were innovative.

As a consequence, in no part of Marshall's works is it possible to find the belief in knowledge convergence and diffusion in such a way as to render markets an array of identical firms.

Knowledge and organization are developed not only inside the firm but also in the outside environment. Because Marshall considers institutional diversity, business environments may present different types of relationships among firms either from the same or from different sectors of activity. For example, market making can be diversely performed. Marshall discusses the role of intermediaries, advertisement and brands. Monopolist tendencies as cartels and trusts are also contemplated, as well as financial arrangements.

In this way, business environments are not only approached from the point of view of competition. Cooperation is also considered, because business occurs in a community of interests. So, self-interest and profit maximization objectives do not exclude social cement and institutional analysis.

\section{Industry and Trade}

Industry and Trade is an almost 900 page volume organized in three books and sixteen appendices. It is the work in which Marshall focused the business organization of his time. In this quality, it is the place where big business receives full attention.

As mentioned earlier, Industry and Trade recognizes big business and analyzes it historically and institutionally. Monopolist developments are brought to the centre of the discussion as historical tendencies. In this context, welfare is a delicate issue. Marshall reflected on historical tendencies as objects of attention and regulation, instead of crying over the spilled milk of the lost perfect competition (which he never proposed as a model). 


\subsection{National historical cases of development}

Industry and Trade begins with the most relevant cases of national business organization development at that time: Britain, France, America and Germany are identified in their national stile of development. Each country has the roots of its development sought in history, institutions and geography. The characterizations raised in the first book are used in the two following ones. The next paragraphs present a brief selection of aspects which not only are pointed out as decisive by the author, as are until our days still addressed.

England's industrial and business organization is presented as the first industrial case, ${ }^{18}$ drawing on other countries experience and achievements on commerce and finance in the process of building a commercial society. ${ }^{19}$ England's ascent to economic hegemony was achieved through the improvement of internal and international communications and transportation, by using mercantilist policies externally oriented to enhance national merchants power, by benefiting from wars first as protection from external produce, and later as stimulus for military exports. Her development is presented as a virtuous circle, in which one achievement is succeeded by another: in broadening commercial area, increasing the scale of production, enhancing the initiative and adventure spirit and the practice of innovation. England reaped the benefits of pioneering the enlargement of commerce with the use of enhanced forces of nature applied to production and trade, with increasing returns.

Britain's industrial strength was made of small businesses. The constitution of a capitalist industrial organization with small businesses as elements was spontaneous ("almost inevitably grew up", in his words), and was made possible by the slow change of the techniques of production and the character of goods. ${ }^{20}$ But the pace of innovation was sufficient to make the son of a wealthy manufacturer "find himself undersold by more rugged and powerful man", 21 giving form to a life cycle of firms working against the monopolization of markets. The division of labor among small firms was characteristic of England's industrial districts.

In the last quarter of the nineteenth century, England began to lose terrain not only with the catching-up of other countries but mainly through the emergence of productive activities in which scientific content was important. In chemicals, electricity, pharmaceuticals and explosives Germany took the lead, because of her education investments and research activities in Universities and great firms. Organization, discipline and skill applied to industry are the qualities Marshall point out in Germany. These are combined with associative practices traditionally developed since the middle ages, appearing under the form of restrictions to competition of the cartels. Lastly, Marshall points out the participation of German banks in the institutional arrangements that enabled the huge investments in research and fixed capital that characterize the second industrial revolution, crossed directories and cartel promotion included. It is noteworthy that Marshall sees the hierarchical character of German society as strength and limitation factor at the same time. The strength is seen in the systematic and massive investment and effort; the limitation is seen in the lack of flexibility and stimulus for creativity. ${ }^{22}$

In the case of the United States, ${ }^{23}$ Marshall points out the size of the country, the homogeneity of life stile among a huge population that favors standardization and scale economies, the supply of

\footnotetext{
${ }^{18}$ Industry and Trade, book I, chapters III,IV,V.

${ }^{19}$ This includes human resources, as the acceptance of the Huguenots and other religious groups who brought their skills fleeing from religious persecution.

${ }^{20}$ Industry and Trade, III, XI, 2, p.581

${ }^{21}$ Industry and Trade, I, IV, 2, p.63

${ }^{22}$ The case of Germany is analyzed in Industry and Trade, I, VII.

${ }^{23}$ Industry and Trade, I, VIII.
} 
immigrant labor, the use of railways to integrate the market and the wealth and variety of natural resources. These conditions enabled an independent development experience in relation to international trade, in contrast with the European experience, and favored the use of machinery, the division of labor and the development of the American standardization of products. In sum, all this brought the mastery of mass production. Other institutional conditions are related to moral aspects brought by the immigrant condition of the builders of the nation, with thrift, toleration towards different values as positive factors. Education suited to business is also pointed out.

The above summary of national cases of development is demonstrative of how important History is for the Marshallian vision of capitalism. It renders clear that development is not seen as mechanical process to be followed by every country as a recipe, because institutions, geography and culture matter:

Of course suggestions, derived from the experiences of any one country, cannot safely be applied to the problems of another, until account has been taken of the degree in which each experience depends on circumstances that are not to be found in the other.

(Industry and Trade, III, XI,1, p.579)

Thus, in the last concluding chapters of Industry and Trade, when discussing what should England do about her loss of preeminence in world business organization, Marshall does not suggest that she should copy solutions from the experience of the United States and Germany, but seek in her own roots. He points out "strong individuality [...] [as England's] most important asset", but in need of being supplemented by readiness to cooperate in "tasks that are needed for the proper development of industry but are too large for a single business." 24 Along four chapters dedicated to the issue, we see Marshall detail, for each sector or instance analyzed, the importance of knowledge and organization at work in private and public levels.

\subsection{Dominant tendencies in business organization: entrepreneurship, production and commercialization}

In "Transition to Present Problems of Industry and Trade", the last chapter of the historical comparative part (book I), Marshall introduces the central transformations in course in the business organization of his time, which are detailed in the second book, called "Dominant Tendencies of Business Organization". Besides the indication of technical and scale transformations, he pointed out commercial, managerial and financial changes. ${ }^{25}$

Examining in the Industry and Trade the historical operation of the two sources of increasing returns offered in the Principles (internal and external economies), we find that, in the first phases of industrialization, the enlargement of the market, the availability of material resources and initiative helped the development of skills and secondary industries, with small scale businesses having access to external economies, regionally sharing them in industrial districts. ${ }^{26}$ This was the predominant situation in the first industrial revolution, led by England. However, Marshall observed that further accumulation of capital and the improvement of communications and transportation amplified the importance of internal economies, at the same time weakening

\footnotetext{
${ }^{24}$ Industry and Trade, III,XI,2.

${ }^{25}$ Citations in this subsection are almost exclusively withdrawn from the last chapter of book one, the one that introduces the overall transformations. The detailed examination of each aspect using the chapter of book two and its comparison with contemporary literature is left for further work.

${ }^{26}$ Industry and Trade, I, XIX, 2, p.167, and II, VI, 6, p.288.
} 
the sources of external economies. The author is characterizing the conditions that lead to the second industrial revolution: Powerful firms were enabled to begin production by attracting labor from other localities, and railways, automobiles, telephones and telegraphers made local procurement non-obligatory. In addition, supplementary services could become internally performed inside great firms, huge industrial capitals began to promote the development of technology, and new products became commercialized through the marketing activities of industrial firms, blurring the borders of industrial and commercial activities. Lastly, labor was organized by administrative leadership in firms that brought together thousands of employees. In sum, among the two sources of increasing returns, internal economies were the most important force pushing the development of business organization in the beginning of the twentieth century, in Marshall's view. Just not to forget the small units of business: in spite of all that, Marshall believed that small firms would always have their role in business organization; he believed that their space is even recreated by the growth of big units as their suppliers.

As a detail, we can point out a sharp observation by the author about the relative importance of technical and commercial transformations as sources of internal economies:

Thus, so far as the "productive" side of business is concerned, it may be concluded that - though the volume of output required for maximum efficiency in proportion to capital is increasing in almost every industry-yet, at any given time and, in any given condition of industrial technique, there is likely to be a point, beyond which any further increase in size gives little further increase in economy and efficiency. [...]

But this conclusion does not extend to the "marketing" side of business: for we shall find that, on that side, the advantages of large capitals in competition with capitals of smaller size are constantly increasing almost everywhere.

(Industry and Trade, II,IV,4)

The passage illustrates the importance of analyzing business as a many-sided activity, so that big business can have other determinants besides scale economies in production.

How would we compare Marshall's perceptions to contemporary interpretations of the transformations involved in the second industrial revolution? We must acknowledge that he was able to identify the main transformations in the business environment of his time. But other considerations apply here: despite having identified the main changes that characterized what is nowadays called Big Business, Marshall did not develop the many aspects of the transformation to the point of the integrated, explicit and seminal statement made by Chandler ${ }^{27}$ : that big business is a three-pronged investment transformation, each of the three elements requiring and reinforcing the role of the other two, because commercial and managerial new capabilities are important for big and sustained throughput which, in turn, is mandatory in order to operate big scale with low unitary costs. Though, following Marshall's perception of business organization already offered in the Principles, the elements of the three sides of the transformation are present, and some important connections are offered. In fact, the three elements of the transformation are object of specific chapters on different aspects of the development of business in the second book. ${ }^{28}$ The result is that, even if the theoretical insight of three-pronged

\footnotetext{
${ }^{27}$ Chandler(1977).

${ }^{28}$ Chapter s III and IV, about technical influences on the size of the business unit; chapters V, VI and VII, about markets and marketing; chapters VIII , X, XI and XII about ownership structure and management; chapter IX about financial issues.
} 
transformation is not arrived at, there are many keen observations and interpretative remarks from Marshall to be highlighted. A demonstration of Marshall's achievements on perceiving the nature of the transformations occurred in the business organization can be made by collecting his observations on the capabilities of the entrepreneur/business unit, and comparing them to Chandler's perceptions. This is done bellow.

Reproducing Marshall's perception of the role and capabilities of the entrepreneur already developed in the Principles, Industry and Trade brings it up to date, in terms of the context of the new form of capitalism. Marshall perceived that besides the largeness of the "modern" industrial operations, technical factors became more complex, requiring a new combination of capabilities from entrepreneurs:

The stage has been passed at which a great idea is almost self-sufficing: it has to be elaborated in connection with others already in possession of the same or neighbouring parts of the industrial field; and its application is therefore not an act, but a long process, needing patience and large resources of mind and perhaps of capital. For instance, when a new mechanical idea has been, created, its translation into a smoothly-working business machine generally involves a long series of experimental stages [...] There is therefore a large class of improvements, [...], which are beyond the range of anyone who does not unite the command of a great business concern, with the possession of high faculty for appreciating new inventions, if not for creating them.

(Industry and Trade, I,IX,3)

Therefore, the new technologies require vision, time, resources and coordination in order to solve the interdependencies inherent to the development of production capabilities, until the point at which the firm can sale the products. The next citation bellow is obtained from Chandler (1994[1990]), in connection with the aspect of competition between first movers and late comers:

[...] mentre i manager di produzione delle imprese inseguitrici iniziano a prendere confidenza con ciò che per loro è una tecnologia nuova o profondamente rinnovata, e mentre vengono assunti e preparati gli addetti alle vendite, $i$ dirigenti delle first movers hanno già eliminato le imperfezioni dei processi produttivi, sono divenuti esperti nell'assicurare la pronta consegna e sono in grado di trovare risposte alle esigenze specifiche dei clienti, fornire dimostrazioni, aprire crediti o, una volta venduto il prodotto, provvedere alla manutenzione e alle riparazioni. Nel caso degli articoli di marca confezionati, per i quali la publicità è un importante strumento di competizione, i first movers hanno già investito parte degli alti profitti, guadagnati grazie al minor costo delle attività, in massicce campagne promozionali.

(Chandler, 1994 [1990], p.62)

As Marshall's last citation above, Chandler's also works with the idea that innovations are worked out after a process, during which the development of capabilities occurs. The new form of business deals with knowledge and mastery of process. The important difference between the two citations refers to Chandler's interdependencies being among productive and other sides of business, related to the throughput requirement.

But we also find in Marshall the observation of change in the capabilities connected to the 
merchant side of the economic activity:

The great business, which is set up far from cognate industries, has to trust very much to its own resources not only on its "productive" side, but also in regard to marketing; that is in regard to buying what it needs and selling what it produces. This points to the facts, [...], that an increasing part of the activity of a manufacturing firm is now given to marketing $[\ldots]$

(Industry and Trade, I,IX,2)

[...] a progressive business must sometimes rouse an interest in its improved and new-fashioned products: and if they are very expensive, $[\ldots]$, the marketing side of the business must be very strong and enterprising and courageous: he who can discharge these functions adequately must include among his qualities and aptitudes those of a great merchant.

(Industry and Trade, I,IX,3)

The marketing side of business in the last Marshallian citations would be deepened with the Chandlerian analysis of the subsumption of intermediaries' tasks under the new firm that verticalized market operations, one aspect of the three pronged transformation. In fact, Marshall, though still approaching some of the relevant aspects of firm's marketing activity in the detailed analysis of Industry and Trade's second book, puts his emphasis in the characterization of the markets of his time, addressing the issues of speculation, the enlargement of retail trade units, and the aspects of brands and advertising in a way that is not equivalent to Chandler's argument; though it does not conflict with it, and we can even find some of its elements, as in the citations above.

The next issue is about managerial capabilities related to the function of leader of men, also made more complex in a giant organization, and also one of Chandler's elements of the triple investment:

[...] the administrative head of a giant business must hold together several thousands of employees of various grades in an order which, while harmonious and disciplined, yet elicits their individual and spontaneous enterprise: and for this he must have some of the chief qualities that are required of the commander of an army. He is not a "captain" of industry; he is a "general" in control of several regiments.

(Industry and Trade, I,IX,3)

However, in the context of the second industrial revolution, hierarchy is not merely a question of men. In a significant way, Marshall could also identify multi-division organization and diversification, with operation divisions centrally conducted by a general office on financial issues, and the synergies that result from the new organization:

Not very long ago a business was almost always concentrated in one place: it might have agencies and branch offices elsewhere; but they were under the control of the central bureau.

Now, however, a single company frequently owns several large establishments engaged in the same or allied branches of a great industry; each of them being self-contained as regards plant, material and executive, though all are under the 
same supreme financial control. So far as technical efficiency is concerned, each of these establishments is a separate business. But the central control can bring the experience of each part to bear in guiding the whole: and can defray the costs of large experiments, the benefit of which will be available to the whole. Again, each may have some advantage in being secure either of a good market for its products, or of a good supply of its own requirements in halffinished products, from some of its sister establishments acting under orders from the directors of the one financial business that includes them all. Further the technique of each establishment may be indirectly strengthened by the opportunity afforded to it of keeping expensive specialized plant in nearly continuous activity on a relatively small range of work; while other parts of orders, coming to the central bureau, are told off to different establishments, which also work intensively within a narrow range. In so far as this can be done the technical efficiency of the business as a whole appears to correspond rather to its aggregate capital than to that which is invested in any one of its establishments.

(Industry and Trade, I,IX,3)

The passage above is comparable to another one from Chandler (1990), being Williamson (1971) the theoretical reference:

Possiamo quindi definire l'instituizione che stiamo analizando, l'impresa industriale moderna, come un raggruppamento di unità operative, ciascuna dotata di propri e specifici mezzi di produzione e personale, le cui risorse e attività sono coordinate, controllate e allocate in un modo integrato da una gerarchia di manager di medio e alto livello. È l'esistenza di questa gerarchia a rendere le operazione dell'impresa nel suo insieme qualcosa de diverso dalla soma delle attività delle singole unità operative.

(Chandler, 1994 [1990], p.34)

The passages refer to the organizational transformation which gives the firm not only functional but also strategic competitivity. Both stress the fact that the new organizational design is more than the sum of the component parts, and the new role of hierarchy and control.

\subsection{Dominant tendencies in business organization: ownership and control of firms}

One of the aspects treated by Marshall in the second book of Industry and Trade was recurrently discussed during the twentieth century and is still a central contemporary issue: the structure of ownership and management of firms. ${ }^{29}$ Marshall observed that large firms were already appearing in the scene as corporations, that is, stock-owned firms managed by professionals. He saw the joint-stock structure of property as causing an inevitable loss of dynamism in capitalism, because of the slack related to the separation of ownership and management.

According to Marshall, stockholders are basically people without business knowledge making business. But they are the people who take the risk. The owner manager of the family firms was in his opinion the ideal form of entrepreneurship, because he would combine the qualities of specific knowledge and profit seeking. A problem with family firms as seen by Marshall was that they were limited in their growth by increasing distances and custom duties. ${ }^{30}$ Besides, as

\footnotetext{
${ }^{29}$ Industry and Trade, II, VIII.

${ }^{30}$ This point can be further explored with the work of recent economic historians. Payne(1974) observes that English industrial family firms did not have the managerial resources to increase their sales, and were dependent on commercial intermediaries for the marketing of their goods.
} 
already commented, he pointed out that the energy and initiative characteristic of successful founders do not remain strong for a sufficient time to grant monopoly to the firm, neither are they transmitted to the next generations.

Marshall observed that joint stock companies show advantages and disadvantages when compared to family firms. As the balance in terms of costs would be in their favor, they would survive and dominate the scene even presenting important flaws.

Among the advantages of joint stock companies are the capacity to hire new managers (and to pay their high wages, because the great quantity produced dilutes the burden), and to have better access to cheap credit and to new technologies. They can reap economies of scale not only in production but also in the commercial field which, as seen, Marshall believed to be the main advantage of size.

The disadvantages of joint stock companies, according to Marshall, are related to the quality of management, because of the separation of ownership and control. Corporations would not have, as family firms do, owner-manager as decision-makers who combine in the same person the qualities of knowledge of the business and the focus on profits. He saw corporations characterized by vis inertiae, with consequential difficulties in mobilizing initiative and surpassing immobility, manifested as difficulty in reorganizing part of the business, or in the closing of an old and obsolete plant. Salaried managers were seen by Marshall as risk averse, only accepting changes that would be successful for sure. Announcement of changes needed would also raise problems of looking like criticizing former administrations; additionally, with advantages not easily proven, argumentation with scattered owners would make changes difficult.

Even with the problems raised by Marshall, corporations would in his view still be more competitive than family firms because of their scale of operation. They would be able to behave with reduced vigor without closing doors and, as a consequence, routine and slack would be predominant in the business environment. Routine and slack are stressed by a comparison of the bureaucracy of a big firm with the bureaucracy of the government, in the sense that both are not, according to him, the ideal environments to breed new ideas and creative experiments.

Marshall's comparison of the last paragraphs and the remarks on the performance of non-owner managers are in line with the contemporaneous economics paradigms of principal-agent relations and governance of firms. Instead of Chandler, the connections here would be referred to other authors. ${ }^{31}$ We must however observe that the problem of governance is a complex issue that demands historical institutional discussion, besides logical considerations. We can amass evidence that will show that corporations have developed organizational solutions to deal with motivation, delegation and information in a way that competition is performed with efficiency. Marshall would not disagree with the assertion that the joint-stock arrangement was the capitalist system solution for dealing with the size exigencies of technology, mass production and marketing from the second industrial revolution on. ${ }^{32}$ On the other hand, evidence can also reveal how there were periods of speculation and mergers that, related to the corporation institutional design, carried flaws similar to the ones pointed out by Marshall, which is, generally speaking, lack of information from the part of the stock-investors, with consequences of bad economic

\footnotetext{
${ }^{31}$ Berle and Means (1930) is considered the work that introduced the theme of separation of ownership and control; slack in management was commented by Marris (e.g. 1963); a classic reference for the agent-principal perspective is Jensen and Meckling (1976).

${ }^{32}$ In fact, we can consider this as an implicit point made by Marshall in Industry and Trade.
} 
performance in the economic system.

\subsection{Monopolistic tendencies}

Marshall also observed that the growth of firms and industry was assuming the institutional form of combinations, as in the case of the American trusts and German cartels, which he analyzed in the third and last part of the book. As already noted, as an analyst of business organization, Marshall saw these tendencies as historical, and tried to understand which the conditions were that would bring a healthy economic environment, even with combinations, growth in size and in market power. In this respect, Marshall is an admirer of the American experience, because in that country court judgments of monopolistic cases were complemented by the constitution of special agencies to study, propose principles and take the initiative of judicial action against firms that would menace the welfare with their economic power. ${ }^{33}$ In this way, he expressed in the beginning of the twentieth century the opinion that society must deal with monopolies with institutions, that is, competition must be regulated with a well informed choice of principles and instruments for control.

In judging what would be fair competition in the historical stage in which innovation and large scale where the rule, Marshall does not regret the lost nineteenth century ideal world of small firms and price takers. Marshall observed that even monopolists face limits to price in competition (no contradiction here), because they must care for the potential competitors that would show up if prices where too high. In this way, there would be limits to high prices because factors that later were called barriers to entry would make possible prices above costs, though within the limits of not attracting newcomers to the market. Besides, Marshall argues that trusts' objectives are long run characterized, and extraordinarily high prices can only be temporary. ${ }^{34}$

By the way, even in the Principles, it was not clear at all, for Marshall, that environments characterized by monopolistic tendencies and increasing returns would harm public interest in terms of prices and quantities:

[...] where it can be made [to assume the single firm to be managed with ability and enterprise, and to have an unlimited command of capital], we may generally conclude that the supply schedule for the commodity, if not monopolized, would show higher supply prices than those of our monopoly supply schedule; and therefore the equilibrium amount of the commodity produced under free competition would be less than that for which the demand price is equal to the monopoly supply price.

(Principles, V,XIV,5)

Still another limit to monopolization is envisaged through the notion of a competitive world in the dynamic sense. Firms that rest on their achievements and profit from their eventual monopoly and cease to innovate would end by losing their market, whatever should once be their market power.

Lastly, Marshall professed approval of some normative criteria observed in the American way of dealing with monopolistic tendencies in his time. They were the standards that could orient justice, commissions and bureaus in judging fair and unfair competition. Here we see that fair competition would be promoted with the aid of an adequate institutional and legal structure. This should have answers for the questions: how should the limits to be imposed on strategic moves

\footnotetext{
${ }^{33}$ Industry and Trade, III, VII,3 and 4.

${ }^{34}$ Industry and Trade, III,VII,5.
} 
by the agents be conceived? When are strategic moves to be considered as harming the wellbeing of society? The Marshallian answer would be that, in a world in which innovation and increasing returns favor size and market power, firms that do not cope with the pace of progress can be left to fall behind on the basis of market forces; ${ }^{35}$ on the other hand, practices that are purposefully aimed at impeding a competitor's performance instead of improving the actor's one should be judged unfair. ${ }^{36}$

\section{Conclusion}

For most of the twentieth century, mainstream economists have been thinking in market functioning having perfect competition in their mind set. ${ }^{37}$ In this condition, increasing returns is an aspect of economic life and a category of economic theory which causes an uneasy condition for economics, because of its non reconcilability with perfect competition.

This paper made the point that Marshall had a different view about the dilemma. It was not at all a dilemma for him, because of his specific concept of competition, and his original analysis of firms. Actually, in an environment in constant change, which is a good representation for the capitalist economy, increasing returns are part of competition, and are neither accessible to all firms nor instantaneously accessible to any firm. Additionally, understanding monopolist tendencies as part of the twentieth century world, and the increasing returns associated to it, Marshall turned to analyzing those tendencies and thinking about their regulation, instead of having an ideal world to use as an impossible guide. In his theoretical analysis and in his way of thinking, there is still competition even with monopolist tendencies.

A methodological remark also applies. We cannot refrain from observing that the perceptions here selected were possible to Marshall because, not having in mind a highly abstract and theoretical world (as would be perfect competition for example), he was always building bridges between theory and his observations. And so, understanding the theoretical importance of commercial issues - making markets, the role of intermediaries, firm's selling efforts - and most of all, the importance of knowledge and organization, he could observe and state the differences between the English capitalism of the nineteenth century and the "new form of capitalism" he was facing, if we want to accept Chandler's underline of this quality of Big Business environment. ${ }^{38}$ And this can be associated to Marshall' methodological procedures, of combining observation and history with theory, observation being loaded with theory and theory not developed as a long deductive chain. The Marshallian method here described stands as a historical-institutional approach to economic problems, with knowledge and organization as main categories of the approach.

The paper also pointed out Marshall's work as an anticipation of modern approaches and modern themes. He was able to grasp, at the very moment of changes, the organizational elements of development, the problems of governance of firms and the monopolistic tendencies. He was also able to identify some general principles on the adequate way to deal with them.

A last and additional remark makes itself necessary. ${ }^{39}$ What has been here exposed does not refute that Marshall was effectively the champion of the family-owned and-managed firm. In

\footnotetext{
${ }^{35}$ Industry and Trade, III,VII,4.

${ }^{36}$ Industry and Trade, III, VII,3.

37 This statement is more defensible and less candid than would appear at first sight. Coase reminds us that economists label "imperfect" things they cannot understand; in the same way, theoretical propositions that depart from perfection may still have perfection as the underlying ideal.

${ }^{38}$ Chandler (1990), p.13.

${ }^{39}$ I must thank Tizziano Raffaelli and Brian Loasby for their comments on this issue.
} 
fact, he was convinced that the industrial district, with its small family firms, was the ideal environment for social and economic development. But this is material for another paper.

Bibliographical references

Chandler, Alfred D. Scale and Scope: The Dynamics Of Industrial Capitalism. Cambridge, Belknap P. of Harvard U.P., 1990. Italian edition of 1994, Bologna: Il Mulino used.

Chandler, Alfred D The visible hand: the managerial revolution in American business. Cambridge, Harvard U.P., 1977.

Chandler, Alfred D. "Organizational capabilities and the theory of the firm". Journal of Economic Perspectives v.6, n.3, p.79-100.

Coase, Ronald H. "Marshall on method". IN: R.H. Coase, Essays in economics and economists. Chicago, University of Chicago Press, 1994. Reprinted from Journal of Law and Economics, 18:25-31, April 1975.

Groenewegen, Peter A soaring eagle: Alfred Marshall 1842-1924. Cheltenham, UK and Northampton, USA: Edward Elgar, 1995.

Hart, Neil. "Equilibrium and time: Marshall's dilemma." Journal of Economic Methodology 3(2):285-306, 1996.

Jensen, M; Meckling, W. (1976) "Theory of the firm: managerial behavior, agency costs and ownership structure". Journal of Financial Economics v.3, pp. 305-60.

Marris, R.(1963) "A model of the managerial enterprise". Quarterly Journal of Economics, v.77, p. 185-209.

Langlois, R; Foss, N.J. "Capabilities and Governance: the Rebirth of Production in the Theory of Economic Organization" Kyklos 52(2):201-218, 1999.

Loasby, Brian The mind and method of the economist. Aldershot: Edward Elgar, 1989.

Marshall, Alfred Principles of Economics. London: Macmillan, 1920, $8^{\text {th }}$ edition.

Marshall, Alfred Industry and Trade. A study of industrial technique and business organization; and of their influences on the conditions of various classes and nations. London: Macmillan, 1919.

Payne, P.L. "Entrepreneurship in the nineteenth century." IN: L. Clarkson, The Industrial Revolution. A Compendium. London: Macmillan, 1990.

Sraffa, Piero "The laws of return under competitive conditions". The Economic Journal 36:535560.

Stigler, George J. "The division of labor is limited by the extent of the market". The Journal of Political Economy 59(3):185-193, June 1951.

Whitaker, John K. "What happened to the second volume of the Principles? The thorny path to Marshall's last books. IN: J.K. Whitaker, Centenary essays on Alfred Marshall. Cambridge University Press, 1990.

Williamson, Oliver E. "Managerial discretion, Organization form and the multi-division hypothesis". IN: Robin Marris and Adrian Wood, The corporate economy. London and Basingstoke: Macmillan, 1971. 